\title{
Comparative Study of Silampari Kayangan Tinggi Dance and Sambut Silampari Dance at Lubuklinggau City
}

\author{
$1^{\text {st }}$ Ninda Levia \\ Dep. Cultural Arts Education \\ Faculty of Social Science Education, \\ Universitas Negeri Padang, Padang, Indonesia \\ ninda9levia@gmail.com
}

\author{
$2^{\text {nd }}$ Indrayuda* \\ Dep. Cultural Arts Education \\ Faculty of Social Science Education, \\ Universitas Negeri Padang, Padang, Indonesia \\ indrayudanur@gmail.com
}

\begin{abstract}
Analyzing the differences and similarities between Silampari Kayangan Tinggi Dance and Silampari Sambut Dance is the main objective in writing this article. This research uses descriptive method, and the type of research is qualitative. The object of this research is the Silampari Kayangan Tinggi Dance with the Sambut Silampari Dance in Lubuklinggau. Data collection technique done by literature review, observation, interview and documentation. This data is analyzed by using the following steps: (1) data collecting, (2) data selecting, (3) data presenting, (4) testing and data conclude. Research result show the
\end{abstract}

\section{INTRODUCTION}

Lubuklinggau is the capital of the Marga Sindang Kelingi Ilir Onder District Musi Ulu. In [1], the City of Lubuklinggau became an autonomous region in 2001. The City of Lubuklinggau requires strategic management to launch city development which has been going fast as well as finding and determining steps to solve all the problems being faced, also as an anticipation of the development of the city. This management is expected to be able to develop and manage the City of Lubuklinggau to become a transit city in a more advanced metropolitan area. The city of Lubuklinggau has customs and culture that show its community identity.

Culture is a guideline for the realization of the behavior patterns of supporting societies as cultural knowledge. Some cultural knowledge consists of, a model device for viewing, understandings, choose what will be faced, devise an action and determine attitudes, actions, and strategies [2]. According to traditional dance is a cultural heritage that must be preserved [3].
Silampari Kayangan Tinggi Dance is different from Sambut Silampari Dance. The difference can be seen from the form of dance, the costume. Both dances is having the same process, the difference is the content that is in the tepak. The Silampari Kayangan Tinggi Dance is more interested in the community when compared to Sambut Silampari Dance. The community assumes the Silampari Kayangan Tinggi Dance more interesting and looks more modern in the presentment.

Keywords-Silampari Kayangan Tinggi Dance, Sambut Silampari Dance, Comparative Study

\section{Silampari Kayangan Tinggi and Silampari Sambut} Dance are dances that have the same regional background. This dance is inspired by folklore namely the Dayang Torek and the Bujang Penulup story. The Silampari Kayangan Tinggi and the Sambut Silampari Dance both tell of women who became fairies. In the story a fairy is past or disappeared. So this dance is called Silampari or fairy that disappeared. The Sambut Silampari Dance became a struggle between the districts and city communities, the city of Lubuklinggau took the Dayang Torek story with the name Silampari Kayangan Tinggi Dance and Musi Rawas District took the Bujang Penulup Story with the name of the Sambut Silampari Dance. The accompanying music used in this dance originally used music equipment such as drums and small gongs, after the dance instruments were updated, the musical instruments used were like guitar, violin, and saxophone. The musical instruments used by the two dances are almost the same, but the music of the two dances by very different according to the synopsis of each dance. 
The Silampari Sambut Dance and the Kayangan Tinggi Silampari Dance were originally used to welcome the great guests who came to the City of Lubuklinggau. In this dance performance, the Sambut Silampari and the Sambut Silampari Kayangan Tinggi Dance both carry a cheer in the form of pat. Tepak is a place to put the requirements that have been set as a symbol of honor for the great guests who come / visit. The Silampari Dance is danced by 7 dancers namely 5 female dancers and 2 male dancers. While the Kayangan Tinggi Silampari Dance is danced by only 5 female dancers.

At the moment, Silampari Kayangan Tinggi and Sambut Silampari Dance are displayed at guest greetings, weddings, and other social events. Silampari Kayangan Tinggi Dance is more in demand by the people around the city, people consider Silampari Kayangan Tinggi Dance more interesting when compared to the Sambut Silampari Dance [4]. The community is enthusiastic about the local arts in the city of Lubuklinggau. It is proven that the community still performs this dance. But the Lubuklinggau city community is currently more dominant using the Silampari Kayangan Tinggi and the Sambut Silampari dance to show.

Both of these dances were created for the welcoming ceremony and were created by the same choreographer. But in reality in its use Silampari Kayangan Tinggi dance has more a place in the eyes of the community. Thus, the two dances are currently dances that play a role and are used in the same activities, with the same function, and also the same creator. But the reality in its activities there are differences in aspects of the quantity of use and distribution.

Based on the description that has been explained above, the researcher is interested in exploring how the comparison between Silampari Kahyangan Tinggi Dance and Sambut Silampari Dance. Therefore, the title proposed in this research is "Comparative Study of the Khayangan Tinggi Dance with the Sambut Silampari Dance in Lubuklinggau City." This study compares the Silampari Khayangan Tinggi Dance with the Sambut Silampari Dance, how the dance forms and the dance differences.

\section{METHOD}

This research uses qualitative and analytical descriptive methods. According to Bodgan and Taylor quoted by [5] qualitative methodology as a research procedure that produces descriptive data in the form of observations, both written and oral delivery and observed community behavior. The instrument in this study was the researchers themselves and supplemented with supporting instruments. In this case the supporting instruments used are stationary to record data from interviews and observations, photo cameras and videos for the documentation of research results. This research produces primary data and secondary data.

Ways or techniques to obtain and collect data are literature study; field observations and documentation at the time the research take place. The data obtained will be reelected, so that it is in accordance with the problems that have been raised, namely about the Comparative Study of the Kayangan Tinggi Dance with Sambut Silampari Dance in Lubuklinggau City. After the selection, the resulting data is arranged systematically and descriptively. After that, the data that have been collected is analyzed again using interpretation techniques and must be carefully considered to produce data that can be trued and reach the object of the study, and answer the problems in the study. The results of the data management will provide the results of the Comparative Study of Kayangan Tinggi Dance with Sambut Silampari Dance Lubuklinggau City.

\section{RESULTS AND DISCUSSION}

\section{The Origin of the Kayangan Tinggi Silampari Dance and the Silampari Sambut Dance}

The Sambut Silampari dance and the Silanganari Kayangan Tinggi dance are traditional dances owned by the people of the city of Lubuklinggau [6]. Sambut Silampari dance and Silampari Kayangan Tinggi dance in Lubuklinggau city have a form of movement that is still very simple and still uses a lot of repetition. In contrast to the dance that does not reflect the lives of the surrounding community, or the silampari community. This dance is a local folk dance that has not been worked out perfectly. However Sambut Silampari dance and Silampari Kayangan Tinggi dance have close relations with legends in 
the city of Lubuklinggau. [7]

The legends related to the story of the Sambut Silampari Dance and Silampari Kayangan Tinggi Dance are the Dayang Torek legend and the legend of the Bujang Penulup and the Seven Angels. The word Silam comes from the local language which means lost, and Pari interpreted as a fairy. So the Silampari can be interpreted as a lost fairy. Besides being used for giving dance to the region, the word Silampari is also used as a regional nickname i.e. Bumi Silampari Lan Serasan Sekentenan which can be interpreted as a peaceful earth, working together, tolerance and help each other.

According to Ayu's mother as the owner of a studio in Lubuklinggau, the Silampari Kayangan Tinggi Dance was remade. Guided by folk dance that is often used during the colonial period and at the beginning of independence. The Silampari Kayangan Tinggi Dance is re-processed until its movements reflect folk dance. The initial performance of the Silampari Kayangan Tinggi Dance was first performed at a dance competition and regional song competition throughout the South Sumatra Province in Lubuklinggau City, in 2004.

\section{The Function of Silampari Kayangan Tinggi Dance and the Sambut Silampari Dance}

- As a traditional dance or welcome dance that is staged in welcoming the great guests visiting the city of Lubuklinggau.

- As a regional identity symbolized as wealth, luxury, splendor and hospitality of the people of the city of Lubuklinggau to visiting guests.

- As a symbol or symbol of honor, one of the dancers carries a tepak containing betel. This means that the people of Lubuklinggau city receive these guests.

- As legitimacy, when an official guest / official / great guest arrives, the greeting must use the Kayangan Tinggi Silampari dance or the Sambut Silampari dance by presenting cheeks filled with betel, lime, and gambier.

- As an educational medium, this dance is preserved for cultural heritage.

- As entertainment or spectacle.
Kayangan Tinggi Silampari Dance moves and Sambut Silampari Dance

The dance movements of the Silampari Kayangan Tinggi Dance are different from the movements of the Sambut Silampari Dance. The Silampari Kayangan Tinggi Dance consists of 8 (eight) movements while the Sambut Silampari dance consists of 11 (eleven) movements. Here are the differences in motion between the Silampari Kayangan Tinggi Dance and the Sambut Silampari Dance:

Table 1 Comparasion of Silampari Kayangan Tinggi and Sambut Silampari Dance

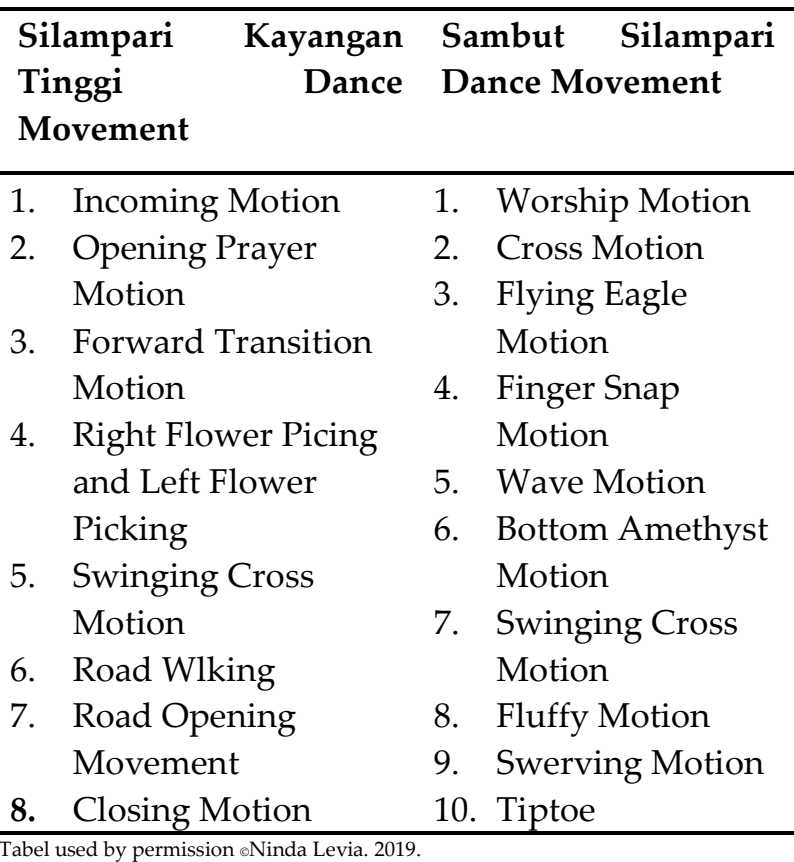

Floor Patterns of the Silampari Kayangan Tinggi Dance and the Sambut Silampari Dance

The floor pattern is the arrangement of lines crossed by the dancers, the arrangement of the floor lines arranged as a formation in a dance. The floor pattern of the Silampari Kayangan Tinggi Dance and the Sambut Silampari Dance use straight lines and curved lines. The lines used in making a floor pattern are vertical, diagonal, and horizontal lines which are straight lines [8]. The use of horizontal lines on the floor pattern makes the floor pattern itself look simple. Straight lines can be used as zigzag and triangle formations. While a soft impression like a circle can be produced using curved lines. 


\section{Cosmetology of Silampari Kayangan Tinggi Dance and Sambut Silampari Dance}

Cosmetology is the arrangement or face painting in order to match the character or theme of the dance that will be performed in the Silampari Kayangan Tinggi Dance and the Sambut Silampari Dance. The makeup that was used in the performance of the Silampari Kayangan Tinggi Dance and the Sambut Silampari Dance was beautiful makeup. This dance uses beautiful makeup because it wants to depict like a fairy who is dancing graceful.[9]

\section{The Clothing of Silampari Kayangan Tinggi} Dance and the Sambut Silampari Dance

Clothing or dress codes are all provisions that have been established as dancers' attire in traditional dance that is adjusted to the meaning of local traditional dance.[10]

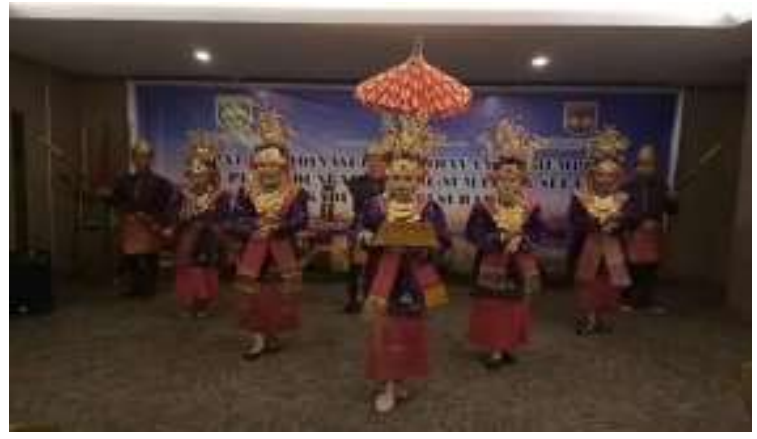

Figure 1 Clothing of Sambut Silampari

Image used by permission @Ninda Levia. 2019. Sambut Silampari Dance and Silampari Kayangan Tinggi Dance in Lubuklinggau City.

Table 2 Comparasion of Clothing Silampari Kayangan Tinggi Dance \& Sambut Silampari Dance

\begin{tabular}{lll}
\hline $\begin{array}{c}\text { Silampari Kayangan } \\
\text { Tinggi Dance }\end{array}$ & \multicolumn{1}{c}{$\begin{array}{c}\text { Sambut Silampari } \\
\text { Dance }\end{array}$} \\
\hline 1. Sewet Songket & 1. Sewet Songket \\
2. Baju Korong & 2. Baju Korong \\
3. Cempako/ Banyan & 3. Cempako / Banyan \\
4. Bird Bracelet & 4. Gelang Kano \\
5. Gelang Kano & 5. Kalong Kebo \\
6. Kalung Kebo & Munggah \\
Munggah & 6. Pendir Ikat \\
7. Pendir Ikat & Pinggang \\
Pinggang & 7. Kembang Urai \\
8. Kembang Urai & 8. Aerrings \\
9. Aerrings & 9. Bun \\
10. Bun & 10. Pilis \\
11. Pilis & 11. Gandik \\
12. Gandik & & \\
\hline
\end{tabular}

Table clothing used by permission @Ninda Levia. 2019. Sambut Silampari Dance and Silampari Kayangan Tinggi Dance in Lubuklinggau City

The Property of Silampari Kayangan Tinggi Dance and Sambut Silampari Dance

Property is a tool used by dancers in performing a performance. The function of property is to describe a character in a performance.[11] Property itself means that the equipment is brought or played when the dancer performs a dance performance. Various forms of property can be in the form of arrows, spears, fans, lights, masks and etc. Making property can be made using iron, wood, plastic, fabric, leather and copper.

Table 3 Comparasion Of Property Silampari Kayangan Tinggi Dance \& Sambut Silampari Dance

\begin{tabular}{ll}
\hline $\begin{array}{c}\text { Silampari Kayangan } \\
\text { Tinggi Dance }\end{array}$ & \multicolumn{1}{c}{$\begin{array}{c}\text { Sambut Silampari } \\
\text { Dance }\end{array}$} \\
\hline 1. Tepak ( contains sirih & 1. Spear \\
leaf \& calk) & $\begin{array}{l}\text { 2. Umbrella } \\
\text { 3. Tepak (contains } \\
\end{array}$ \\
& $\begin{array}{l}\text { sirih leaf, calk, } \\
\text { areca nut and } \\
\end{array}$ \\
& gambier) \\
\hline
\end{tabular}

Table property used by permission $\oplus$ Ninda Levia. 2019

Sambut Silampari Dance and Silampari ayangan Tinggi

dance in Lubuklinggau City

\section{Music/Accompaniment}

Music in a dance performance is needed. Dance music can be created through components that exist in the dancers themselves based on a predetermined motion. For example by clapping hands, stomping feet, the sound of the dancer's mouth. There is also music from external sources that uses music instruments played by musicians. Every dance work certainly needs music, this is because music and dance cannot be separated. Dance and motion music is a unity and cannot be separated. Music in a dance that is functioning as an accompaniment of dance work can also liven up the atmosphere in a dance work, and as an accent and illustration of a dance work. Music is also like dictating a dance work, the duration, atmosphere and style of dance.

Silampari Kayangan Tinggi Dance and Sambut Silampari Dance use the music. Silampari Kayangan Tinggi Dance music has different music used in the Sambut Silampari dance performance. Each 
dance has its own uniqueness and characteristics in accordance with the flow and description of each dance.

Table 4 Comparation of instrument used in Sambut Silampari Dance

\begin{tabular}{lll}
\hline \multicolumn{1}{c}{ Dance } & \multicolumn{2}{c}{$\begin{array}{c}\text { Sambut Silampari } \\
\text { Dance }\end{array}$} \\
\hline 1. Accordion & 1. Biola \\
2. Djimbe & 2. Accordion \\
3. Bass & 3. Gong \\
4. Gendang Besar & 4. Gendang Melayu \\
5. Gendang Lonjong & 5. Ketawak \\
6. Rebana Besar & & \\
7. Bonang & & \\
\hline
\end{tabular}

Table used by permission $\odot$ Ninda Levia. 2019.

Table 5 Comparation Of Silampari Kayangan Tinggi Dance \& Sambut Silampari Dance

\begin{tabular}{ll}
\hline \multicolumn{1}{c}{$\begin{array}{c}\text { Silampari Kayangan } \\
\text { Tinggi Dance }\end{array}$} & \multicolumn{1}{c}{$\begin{array}{c}\text { Sambut Silampari } \\
\text { Dance }\end{array}$} \\
\hline $\begin{array}{l}\text { Silampari kayangan tinggi } \\
\text { Silampari kayangan tinggi }\end{array}$ & $\begin{array}{l}\text { Silampari pusaka } \\
\text { budaya Lambang } \\
\text { Name tu sebab name tu }\end{array}$ \\
sebabmur & Jiwa nusa bangsa \\
La panjang kameru & \\
panjang & Pribadi bumi sejarah \\
Name tu sebab name tu & negri Musirawas asli \\
sebab & Pribadi bumi sejarah \\
La panjang kameru & negri Musirawas asli \\
panjang & \\
& Pancasila dasar \\
Lae layang disayang & hidup bangsa \\
Slamat datang kami & Sigap tegap putra \\
ucapkan & dan putrinya \\
Slamat datang kami & Menuju cita- cita \\
ucapkan & Bersama Indonesia \\
Para hadirin para hadirin & jaya \\
Ya sayang di lubuk & Menuju cita- cita \\
linggau & Bersama Indonesia \\
Para hadirin bapak dan ibu & jaya \\
Ya sayang di lubuk & \\
linggau & \\
Lae layang disayang & \\
Nak memacung salak & \\
serumpun & \\
Nak memacung salak & \\
serumpun & \\
Depat dijuluk depat & \\
\hline & \\
&
\end{tabular}

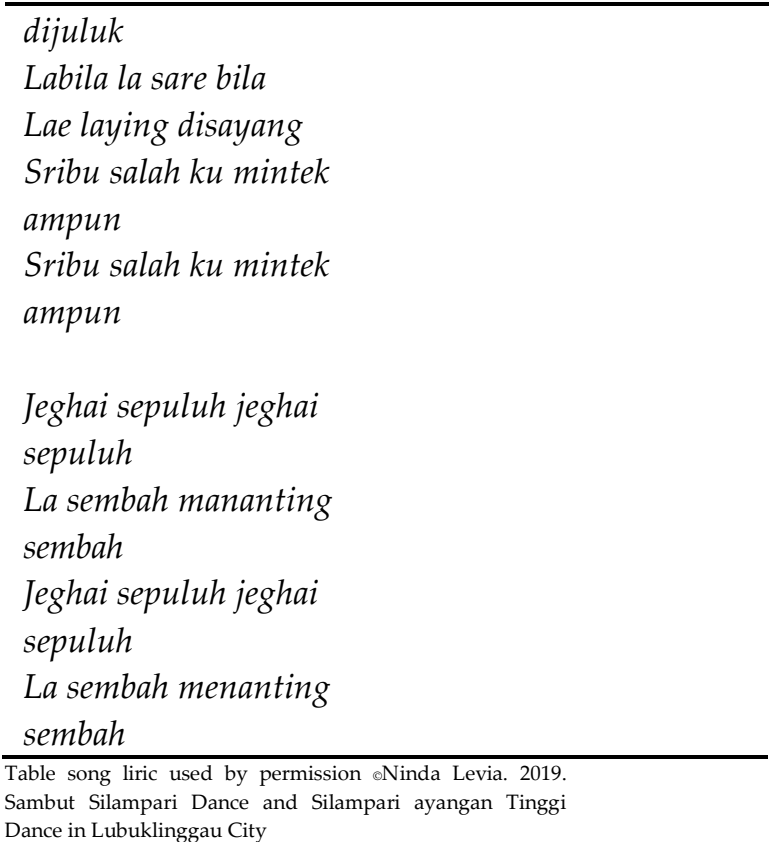

\section{CONCLUSIONS}

The results of this thesis can be concluded that, the comparative study or comparison of the Silampari Kayangan Tinggi Dance and the Sambut Silampari Dance have seen similarities and differences. In terms of similarities, it can be seen from the history of the Silampari Kayangan Tinggi Dance and the Sambut Silampari Dance that both originate from the same story, that is the story of Dayang Torek, Bujang Penulup and Tujuh Bidadari. Seen from its function also the Silampari Kayangan Tinggi Dance and the Sambut Silampari Dance have the same function namely, (1) as a traditional dance or traditional dance, (3) as a symbol / symbol of honor for reception, (4) as legitimacy when great guests / regional officials come, and (5) as an educational medium.

The difference in the Silampari Kayangan Tinggi Dance and the Silampari Sambut Dance can be seen through several things such as the use of motion, number of dancers, floor patterns, musical instruments, song lyrics and the use of dance costumes. Motion in Silampari Kayangan Tinggi Dance has 12 (twelve) movements, while the Sambut Silampari Dance has 10 (ten) motions. The number of dancers in the Silangan Dance Kayangan Tinggi is 7 (seven) people, danced by 2 (two) male dancers and 5 (five) female dancers.

The floor pattern of the Silampari Kayangan Tinggi Dance and the Sambut Silampari Dance use straight lines and curved lines, but each dance has 
a different floor pattern. After the floor pattern, there is a difference and one similarity is also seen with the musical instrument used. The same musical instrument used in this dance is the accordion music instrument. While musical instruments that are different from Silampari Kayangan Tinggi Dance use musical instruments such as jimbe, bass, large drum, oval drum, large tambourine and boning. While the tools used in the Sambut Silampari Dance are violins, gongs, Malay drums, and ketawak.

Silampari Kayangan Tinggi dance and Sambut Silampari Dance have different song lyrics, the differences in song lyrics are adjusted to the story and needs in accordance with the dance message to be conveyed to the viewing public. Likewise with the clothing and accessories used, clothing in this dance has many similarities, except for the use of slightly different accessories. Besides this dance also uses tepak as property, it's just the stuffing inside of the tepak that distinguishes. Tepak used in the performance of the Sambut Silampari Dance is more complete when compared to the Silampari Kayangan Tinggi Dance. The tepak in the Sambut Silampari dance contain sirih leaf, tobacco, chalk, areca nut and gambier whereas in the Silampari Kayangan Tinggi Dance only contains sirih leaf and chalk.

After the comparison of the high Silampari Kayangan Dance and the Sambut Dance the public can find out the differences and similarities as well as the interesting local arts they have. As more people know about the differences in these two dances, people will be better able to choose which dance will be used in performances at events that will be held. In the comparison described above regarding these two dances, it is clear that community more often use Silampari Kayangan Tinggi Dance, because the presenment of Silampari Kayangan Tinggi Dance is more interesting. It can be seen from the more upbeat movements and musical accompaniment that is more supportive of the Silampari Kayangan Tinggi Dance performance.

\section{REFERENCES}

[1] Republic of Indonesia Law Number 7 of 2001 dated June 21, 2001

[2] Sudikan, Setya Yuwana. (2001). Metode Penelitian Sastra Lisan. Surabaya: Citra Wacana.

[3] Agustin, W., F., Wahyudi, Suyanto, I. (2015). Penggunaan Model Mind Map dalam Peningkatan Hasil Belajar IPS tentang Perkembangan Teknologi Siswa Kelas IV SD Negeri 2 Jatisari Kecamatan Kebumen Kabupaten Kebumen Tahun Ajaran 2015. Jurnal Kalam Cendikia, 4 (1.1), hlm. 19.

[4] Interview Rama Wahyu Sartika on date June 10, 2019

[5] Moleong, Lexy J. (2012). Metode Penelitian Kualitatif. Bandung: PT Remaja Rosdakarya.

[6] Pratiswa, Stepanus Adi. (2016). Rekonstruksi tari Sambut Silampari di Kabupaten Musi Rawas. Gelar: Jurnal Seni Budaya, 12(2).

[7] Novan. (2017). Sejarah Kabupaten Musi Rawas. diakses pada Perpustakaan Digital Kebudayaan Indonesia. 23 April 2019 https://budaya-indonesia.org/SejarahKabupaten-Musi-Rawas.

[8] Tien Kusumawati. (2015). Kajian Koreografi. Jurnal Seni Tari, 4(1).

[9] Kristiani, Rizki. (2017). Rias Korektif untuk Warna Kulit Gelap pada Pengantin Bridal. Universitas Negeri Surabaya E-Jurnal Pendidikan Kesejahteraan Keluarga. 6(2).

[10] Nurdin. (2018). Tata Rias dan Busana Tari Serasan Seandanan Di Kabupaten OKU Selatan. Universitas PGRI Palembang. Jurnal SITAKARA Jurnal Pendidikan Seni dan Seni Budaya, 3(2).

[11] Nugraha, Satria, dkk. (2016). Perancangan Film Feature Tepak Sirih Palembang. Jurnal BESAUNG Seni desain dan budaya. 1(1). 